\title{
Is long-lasting mucosal elevation the only valid parameter when evaluating a lifting agent?
}

This article was published in the following Dove Press journal:

Clinical and Experimental Gastroenterology

12 June 2012

Number of times this article has been viewed

\section{Stefano Pontone \\ Simone Manfredelli \\ Dimitri Krizzuk \\ Giovanni Leonetti}

Department of Surgical Sciences, "Sapienza" University of Rome,

Rome, Italy
Correspondence: Stefano Pontone Department of Surgical Sciences, "Sapienza" University of Rome, V.le Regina Elena 324, Rome 00 I6I, Italy $\mathrm{Tel}+390649972446$

Fax +3906 49972446

Email stefano.pontone@uniroma l.it

\section{Dear editor}

Considering the relevance of the topic, our attention was strongly attracted by the study reported by Al-Taie et al. ${ }^{1}$ This study, based on our experience, ${ }^{2,3}$ begs some questions. Although the limitations of the lifting agent have been correctly identified by the authors, it would be useful to know the timing and details of the procedures used for preparation of blood, plasma, and serum. The quality of the agent used suggests that it behaves, in terms of viscosity and transparency, like a hematoma at the time of endoscopic resection. Thus, endoscopic visibility for detecting the mucosal layers may be affected by the lifting agent, especially when the amount of fluid used exceeds $1 \mathrm{~mL} .{ }^{4}$ Rightly, the authors emphasize that methylene or toluidine blue colorants can be used during submucosal resection without impairing visibility. However, they also have the advantage of highlighting the different wall layers according to different rates of absorption, and they are used in a strong concentration.

As demonstrated by other studies, ${ }^{5-7}$ we used hydroxypropyl methylcellulose (HPMC) as a safe lifting agent for large resections in order to obtain an effective and longer-lasting submucosal fluid cushion. In this regard, we would like to know if the mucosal elevation rate was evaluated during infiltration. In our case, considering the high viscosity of HPMC, we had to perform dilution with a normal saline solution to obtain smoother injection. Furthermore, in the event of excessive infiltration, the advantage of more permanent lifting becomes an obstacle to endoscopic resection. Thus, if the time of dissipation in blood is much higher that HPMC, as reported by Giday et $a 1,{ }^{8}$ the risk of not being able to recover from an excessive injection increases exponentially.

Currently, only the study by Sato ${ }^{9}$ has pioneered the use of blood patch endoscopic mucosal resection, with encouraging results. However, even this technique has been used in only 35 patients, without endoscopic submucosal dissection or an adequate control group, and to treat lesions frequently smaller than $20 \mathrm{~mm}$. Thus, further trials would be needed to validate this type of lifting agent.

In conclusion, although the study reported by Al-Taie et al ${ }^{1}$ is a challenging approach and tries to solve one of the main challenges of endoscopic mucosal and submucosal dissection, our opinion is that device improvements, as in the hybrid knife example, will bypass this obstacle by enabling infiltration and resection using the same device. Thus, the hemostatic properties of the blood patch, once proven, could represent a hoemostatic solution after endoscopic resection. 


\section{References}

1. Al-Taie O, Bauer YB, Dietrich CGD, Fischbach WF. Efficacy of submucosal injection of different solutions inclusive blood components on mucosa elevation for endoscopic resection. Clin Exp Gastroenterol. 2012;5(1):43-48.

2. Quondamcarlo C, Pontone S, Panarese A, Pironi D, Pontone P, Filippini A. Endoscopical en bloc resection of a large duodenal adenoma with focal high dysplasia: hydroxypropyl methylcellulose as a safe lifting agent in a large duodenal adenoma EMR. J Gastrointest Surg. 2011;15(8):1480-1481.

3. Pontone S, Pironi D, Eberspacher C, Pontone P, Filippini A. Endoscopic management of multiple large antral hyperplastic polyps causing gastric outlet obstruction. Ann Ital Chir. 2011;82(4):297-300.

4. Shastri YM, Kriener S, Caspary WF, Schneider A. Autologous blood as a submucosal fluid cushion for endoscopic mucosal therapies: results of an ex vivo study. Scand J Gastroenterol. 2007;42(11): 1369-1375.
5. Arezzo A, Pagano N, Romeo F, et al. Hydroxy-propyl-methyl-cellulose is a safe and effective lifting agent for endoscopic mucosal resection of large colorectal polyps. Surg Endosc. 2009;23(5):1065-1069.

6. Arantes V, Albuquerque W, Benfica E, et al. Submucosal injection of $0.4 \%$ hydroxypropyl methylcellulose facilitates endoscopic mucosal resection of early gastrointestinal tumors. J Clin Gastroenterol. 2010; 44(9):615-619.

7. Bacani CJ, Woodward TA, Raimondo M, et al. The safety and efficacy in humans of endoscopic mucosal resection with hydroxypropyl methylcellulose as compared with normal saline. Surg Endosc. 2008; 22(11):2401-2406.

8. Giday SA, Magno P, Buscaglia JM, et al. Is blood the ideal submucosal cushioning agent? A comparative study in a porcine model. Endoscopy. 2006;38(12):1230-1234

9. Sato T. A novel method of endoscopic mucosal resection assisted by submucosal injection of autologous blood (blood patch EMR). Dis Colon Rectum. 2006;49(10):1636-1641.

\section{Publish your work in this journal}

Clinical and Experimental Gastroenterology is an international, peerreviewed, open access journal, publishing all aspects of gastroenterology in the clinic and laboratory, including: Pathology, pathophysiology of gastrointestinal disease; Investigation and treatment of gastointestinal disease; Pharmacology of drugs used in the alimentary tract;
Immunology/genetics/genomics related to gastrointestinal disease. This journal is indexed on CAS. The manuscript management system is completely online and includes a very quick and fair peer-review system. Visit http://www.dovepress.com/testimonials.php to read rea quotes from published authors.

Submit your manuscript here: http://www.dovepress.com/clinical-and-experimental-gastroenterology-journal 